\title{
REFORMERS ON STAGE
}

Popular Drama and Religious Propaganda in the Low Countries of Charles V,

1515-1556 
This page intentionally left blank 


\section{REFORMERS ON STAGE}

Popular Drama and Religious Propaganda in the Low Countries of Charles V,

1515-1556

Gary K. Waite

UNIVERSITY OF TORONTO PRESS Toronto Buffalo London 
www.utppublishing.com

(C) University of Toronto Press Incorporated 2000

Toronto Buffalo London

Printed in Canada

ISBN 0-8020-4457-3

()

Printed on acid-free paper

\section{Canadian Cataloguing in Publication Data}

Waite, Gary K., 1955-

Reformers on stage : popular drama and religious propaganda in the low countries of Charles V, 1515-1556

Includes bibliographical references and index.

ISBN 0-8020-4457-3

1. Chambers of rhetoric - Benelux countries - History. 2. Dutch dramaEarly modern, 1500-1700 - History and criticism. 3. Theater - Religious aspects. 4. Reformation - Benelux countries. 5. Theater and societyBenelux countries - History $-16^{\text {th }}$ century. I. Title.

PT5267.C5W34 $2000 \quad 839.31^{\prime 2209} 382706 \quad$ C00-930164-X

University of Toronto Press acknowledges the financial assistance to its publishing program of the Canada Council for the Arts and the Ontario Arts Council.

This book has been published with the help of a grant from the Humanities and Social Sciences Federation of Canada, using funds provided by the Social Sciences and Humanities Research Council of Canada.

University of Toronto Press acknowledges the financial support for its publishing activities of the Government of Canada through the Book Publishing Industry Development Program (BPIDP). 
To my sweet Eleanor, whose arrival brought joy immeasurable Also in memory of those whose recent death has brought sorrow:

Grandmothers Annie Waite (d. 1995) and Ethyl Sharpe (d. 1990) Uncle Stewart Warren (d. 1996) and cousins Jean Walsh (d. 1996) and Ruby Blake (d. 1997)

Your love lives still in those left behind 
This page intentionally left blank 